\title{
Evaluation of sperm recovered after slaughter from cauda epididymides of red Sokoto bucks
}

\author{
A. H. Abu' ${ }^{1}$ A. I. Kisani' ${ }^{2}$ and T. Ahemen ${ }^{3}$
}

1. Department of Veterinary Physiology, Pharmacology and Biochemistry, College of Veterinary Medicine, Federal University of Agriculture, P.M.B. 2373, Makurdi, Benue State, Nigeria; 2. Department of Veterinary Surgery and Theriogenology, College of Veterinary Medicine, Federal University of Agriculture, P.M.B. 2373, Makurdi, Benue State, Nigeria; 3. Department of Animal Breeding and Physiology, College of Animal Science, Federal University of Agriculture, P.M.B. 2373, Makurdi, Benue State, Nigeria.

Corresponding author: A. H. Abu, e-mail: adakoleabu1@gmail.com, AIK: abohkisani@yahoo.com, TA: drtahemen@gmail.com

Received: 11-08-2016, Accepted: 15-11-2016, Published online: 18-12-2016

doi: 10.14202/vetworld.2016.1440-1444 How to cite this article: Abu AH, Kisani AI, Ahemen T (2016) Evaluation of sperm recovered after slaughter from cauda epididymides of red Sokoto bucks, Veterinary World, 9(12): 1440-1444.

\begin{abstract}
Aim: Viable spermatozoa could be recovered from the cauda epididymides for the purpose of preservation of genetic material of male animals with desirable traits and for use in reproductive biotechnology. The aim of this study was to determine the effect of storage time on testicular and epididymal biometry, sperm reserves and epididymal sperm characteristics of red Sokoto bucks post mortem.

Materials and Methods: Testes-epididymides were collected immediately after slaughter of mature red Sokoto bucks and transported in ice chest to the laboratory. The samples were either processed immediately or stored at $5^{\circ} \mathrm{C}$ in refrigerator for 24, $48 \mathrm{~h}$ and then processed. The testes and epididymides were measured and weighed. Sperm motility, concentration, livability, morphology, intact acrosome from different treatment groups including control were evaluated and means ( \pm standard error of mean) were recorded.
\end{abstract}

Results: There was no significant difference $(\mathrm{p}>0.05)$ in the testicular and epididymal dimensions determined between the means of the groups. Percent sperm motility and viability decreased significantly $(\mathrm{p}<0.05)$ after $24 \mathrm{~h}$ from $69.00 \pm 0.46$ and $71.27 \pm 0.50 \%$ to $50.60 \pm 0.48$ and $60.47 \pm 0.70 \%$ at $48 \mathrm{~h}$, respectively. Significant decreases $(\mathrm{p}<0.05)$ in epididymal sperm concentration and intact acrosome from $2.86 \pm 0.08$ and $92.87 \pm 0.39$ at 0 to $24 \mathrm{~h}$ of storage, respectively, were observed.

Conclusion: The results of this study suggest that spermatozoa recovered from the epididymides of red Sokoto bucks were viable after storage for up to $48 \mathrm{~h}$. Furthermore, this finding offers some hope that epididymal sperm recovered post-mortem can be used in assisted reproductive technologies.

Keywords: epididymides, goat bucks, spermatozoa, testes.

\section{Introduction}

In the field of animal reproduction, artificial insemination and sperm cryopreservation are methods of reproductive biotechnologies that have revolutionized the livestock industry. Sperm recovered from cauda epididymides can be used in the conservation of animal genetic material and reproductive biotechnology. However, any plan of action for ex situ conservation of animal genetic material of valuable and or endangered male animals requires protocols for the recovery of viable sperm from the epididymides of slaughtered animals.

Instead of the conventional method of semen collection, epididymal sperm is rather collected to reduce costs and because of some organizational difficulties. This becomes necessary when natural

Copyright: Abu, et al. Open Access. This article is distributed under the terms of the Creative Commons Attribution 4.0 International License (http://creativecommons.org/licenses/by/4.0/), which permits unrestricted use, distribution, and reproduction in any medium, provided you give appropriate credit to the original author(s) and the source, provide a link to the Creative Commons license, and indicate if changes were made. The Creative Commons Public Domain Dedication waiver (http://creativecommons.org/ publicdomain/zero/1.0/) applies to the data made available in this article, unless otherwise stated. mating or the use of ejaculated semen is not possible due to difficulty of handling intractable animal or sudden death of an animal [1-3]. Acceptable motility and viability of spermatozoa recovered from the epididymides which have been maintained at room temperature or $5^{\circ} \mathrm{C}$ has been reported in bull [4], boar [5], stallion [6], tom cat [7], and dog [8]. Researchers have reported that the method used to recover sperm from cauda epididymides postmortem does not affect their quality [9]. However, other studies have recorded that quality of epididymal spermatozoa varied according to climactic conditions and temperature [10].

Preservation of sperm cells can be compromised if testis-epididymis samples are poorly packaged or stored due to post-mortem tissue degeneration [11]. Furthermore, time constraint is consistently identified as a major problem for recovering motile and viable epididymal sperm cells from the abattoir-derived testicles and epididymides [5,12]. A Google search through available literature showed a lack of wealth of information on the effect of handling conditions or storage time on the quality of spermatozoa recovered post-mortem from cauda epididymides of local breeds of goats in Nigeria. 
The aim of this study was to determine the effect of storage time on testicular and epididymal biometry, and epididymal sperm characteristics of red Sokoto bucks post-mortem.

\section{Materials and Methods}

\section{Ethical approval}

An ethical approval was not necessary since no live animals were used for this research. However, the samples were collected from a metropolitan abattoir approved by the Benue State Government of Nigeria.

\section{Location of the study}

This study was conducted at the College of Veterinary Medicine, Federal University of Agriculture, Makurdi, Nigeria. Makurdi is situated in the Southern Guinea Savannah and located at Latitude $7^{\circ} 14^{\prime}$ North and Longitude $8^{\circ} 21^{\prime}$ East. The area is warm with temperature range of $24-36^{\circ} \mathrm{C}$ and high temperature is experienced between late February and April. The rainfall is between 508 and $1016 \mathrm{~mm}$. There are two seasons: Rainy season (May-October) and dry season (November-April).

\section{Sample collection and experimental design}

Fresh testes-epididymides contained in scrotal sacs were collected from mature red Sokoto bucks slaughtered at a metropolitan abattoir in Makurdi, Benue state, Nigeria. Samples were individually packaged in polythene bags, placed on ice and transported in ice chest to the laboratory for further processing. On arrival, the testicles were stored at $5^{\circ} \mathrm{C}$ in refrigerator for $24,48 \mathrm{~h}$ post-mortem and then processed $(n=15$ per each treatment group, respectively) while the other testicles (control) were immediately processed $(n=15)$.

\section{Experimental procedure}

In harvesting the testes and epididymides, the scrotal sacs were washed and cleaned with tap water. For thawing the samples, epididymides along with testes were allowed to warm to room temperature $\left(35 \pm 2^{\circ} \mathrm{C}\right)$ for $15 \mathrm{~min}$ and then immersed into a water bath at $37^{\circ} \mathrm{C}$ for $5 \mathrm{~min}$ till the outer surface of the testes as well as epididymides were softened. Testicles were dissected away from the tunica vaginalis and other extraneous tissues during the warming period. A scalpel blade was used to make an incision from the dorsomedial aspect of the testis. The skin of the scrotum was reflected laterally, and the subcutaneous tissue and scrotal fascia were incised to expose the tunica vaginalis. The tunica albuginea was carefully removed from the testis. The epididymis was then carefully separated from the testis using the scalpel blade and thumb forceps. The testes and epididymides were excised, separated and weighed. The lengths of testes and epididymides were also measured using a ruler. The testes and the epididymides were also weighed on a sensitive balance scale (Ohaus ${ }^{\circledR}$, USA).

Spermatozoa were collected from the caudal epididymides at room temperature by the incision method. Several incisions were made on the lower end of the epididymides to enable spermatozoa swim out into prewarmed $\left(37^{\circ} \mathrm{C}\right) 5 \mathrm{ml}, 2.9 \%$ sodium citrate buffer in a petri dish.

\section{Determination of sperm motility}

Sperm motility from different treatment groups including control was evaluated as previously described [13]. Briefly, a drop (100 $\mu 1)$ of sperm sample was placed on a prewarmed, grease-free slide. A cover slip was put over the drop and examined under the microscope (40× magnification), and the percentage of sperm motility was determined.

\section{Determination of sperm concentration}

Sperm concentration of each sample was determined using the improved Neubauer hemocytometer after appropriate dilution in $0.05 \%$ formol-saline as previously described [14].

\section{Determination of sperm viability}

The viability of sperm cells was determined according to the method of Blom [15]. Briefly, a drop of sperm sample was mixed with a drop of eosin-nigrosin stain on a clean slide, and the mixture was allowed to stand for $3 \mathrm{~min}$. Then, the smear was air dried and examined under the microscope $(100 \times$ magnifications). Dead spermatozoa were stained either partially or completely pink or red, and live spermatozoa appeared colorless. 200 spermatozoa were randomly examined, and the percentage of live sperm cells was determined. The mean results were expressed as percent viable spermatozoa.

\section{Determination of acrosome integrity}

The percent intact acrosome was determined according to the procedure previously described [16]. Briefly, a small $(100 \mu \mathrm{l})$ drop of each sample was placed on a clean slide and a smear was made. The air-dried smears were fixed in Hancock's solution for 15-20 min, washed and rinsed with distilled water. The slides were stained with Giemsa working solution overnight, then rinsed with tap water, air-dried and observed under the microscope (100× magnification). 200 spermatozoa were examined, and the percentage of intact acrosome was determined.

\section{Statistical analysis}

Results were expressed as means and standard error of mean. Data were analyzed using one-way analysis of variance with software package (Graph Pad Prism for Windows; http://www.graphpad.com/ scientific-software/instat). For analysis, $\mathrm{p}<0.05$ was considered statistically significant.

\section{Results and Discussion}

Testicular and epididymal parameters are reliable indices of assessing semen producing ability and in evaluation of breeding soundness of animals. This study describes the effect of storage time on testicular and epididymal biometry and cauda epididymal sperm values when abattoir-derived samples were processed 
immediately or stored at $5^{\circ} \mathrm{C}$ for 24 and $48 \mathrm{~h}$, respectively. The mean values for testicular and epididymal lengths and weights in each treatment group (0, 24 and $48 \mathrm{~h}$ ) are presented in Table- 1 . The effect of storage-time on epididymal sperm characteristics of red Sokoto bucks post-mortem are shown in Table-2. Sperm motility, concentration, viability and intact acrosome decreased significantly $(\mathrm{p}<0.05)$ from 0 to $48 \mathrm{~h}$ of storage.

The results of testicular and epididymal morphometry obtained in this study compare favorably with the previous values reported [17] for red Sokoto bucks raised in the savannah zone of Nigeria. The mean testis weight $(81.7 \mathrm{~g})$ and whole epididymal weight $(14.93 \mathrm{~g})$ reported by these authors were higher than the values in this study. These data were similar to the values of the testicular weights (51.79 and $52.23 \mathrm{~g})$ and epididymal lengths $(7.46$ and $7.85 \mathrm{~cm})$ earlier reported by Oyeyemi et al. [18].

Testicular weight and size vary with breed, age and time of the season. In this study, the left testis was larger than the right testis. The significant difference $(p<0.05)$ observed in the ratio of left to right testes weights in the caprine bucks have also been reported in other studies [19]. Males with larger testes tend to produce more sperm [20]; hence a good measurement of testes weight, length and width would be a reliable index of predicting the sperm-producing capacity of bucks [21] and for selection of breeding males [22]. The findings in this study were similar to those reported by Mir et al. [23] who also did not observe significant differences in the mean testicular and epididymal values even after $48 \mathrm{~h}$ post-mortem.

The results of this study showed that cold storage up to $48 \mathrm{~h}$ reduced motility of sperm cells, sperm concentration, viability and intact acrosome (Table-2). In live animals, the cauda epididymides provide a suitable environment for the immature spermatozoa to become mature and acquire motility. Furthermore, studies have shown that spermatozoa recovered from cauda epididymides become motile only when they make contact with seminal fluid or media $[24,25]$ and remain functional even hours after the death of an animal $[12,26]$. There are also reports that the handling conditions of testicles recovered post-mortem have some effect on the viability of spermatozoa [2].

The significant decrease in motility, sperm concentration, viability, and intact acrosome of epididymal spermatozoa recovered post-mortem and maintained under similar conditions have been reported in mice [27], ram [10,28], boar [5], bull [1], stallion [29], and camel [30]. Variation in quality of cauda epididymal sperm cells recovered post-mortem has been ascribed to handling conditions or species differences [31,32]. However, cold storage has the beneficial effect of keeping sperm cells viable for a longer period by slowing down the metabolic rate and degeneration of sperm cells $[4,33]$.

Sperm concentration varies not only between animals but also between species of livestock [34]. The results in this study (Table-2) were higher than the values $\left(0.61 \pm 0.05 \times 10^{9} / \mathrm{ml}\right)$ earlier reported [35] but were within the range $\left(1.12-4.66 \times 10^{\%} / \mathrm{ml}\right)$ previously reported [36] and were also in agreement

Table-1: Mean ( \pm SEM) testicular and epididymal values from red Sokoto bucks' testes collected post-mortem, processed without storage and stored at $4^{\circ} \mathrm{C}$ for 24 , and $48 \mathrm{~h}$.

\begin{tabular}{lccc}
\hline Parameter & \multicolumn{3}{c}{ Storage hours } \\
\cline { 2 - 4 } & $\mathbf{0}$ & $\mathbf{2 4}$ & $\mathbf{4 8}$ \\
\hline Left testis weight $(\mathrm{g})$ & $56.82 \pm 0.62^{\mathrm{a}}$ & $56.93 \pm 0.70^{\mathrm{a}}$ & $56.99 \pm 0.65^{\mathrm{a}}$ \\
Right testis weight $(\mathrm{g})$ & $55.20 \pm 0.59^{\mathrm{b}}$ & $55.75 \pm 0.64^{\mathrm{b}}$ & $55.60 \pm 0.64^{\mathrm{b}}$ \\
Paired testes weights $(\mathrm{g})$ & $112.60 \pm 0.79$ & $112.70 \pm 1.32$ & $114.00 \pm 1.90$ \\
Left testis length $(\mathrm{cm})$ & $6.21 \pm 0.11$ & $6.22 \pm 0.07$ & $6.09 \pm 0.06$ \\
Right testis length $(\mathrm{cm})$ & $6.17 \pm 0.08$ & $6.02 \pm 0.07$ & $6.09 \pm 0.06$ \\
Paired testes length (cm) & $12.52 \pm 0.19$ & $12.21 \pm 0.12$ & $11.87 \pm 0.14$ \\
Whole left epididymal weight $(\mathrm{g})$ & $6.94 \pm 0.04$ & $6.75 \pm 0.10$ & $7.02 \pm 0.05$ \\
Whole right epididymal weight $(\mathrm{g})$ & $6.80 \pm 0.04$ & $6.64 \pm 0.09$ & $6.85 \pm 0.04$ \\
Paired epididymal weights $(\mathrm{g})$ & $13.94 \pm 0.07$ & $13.38 \pm 0.20$ & $13.86 \pm 0.08$ \\
Whole left epididymal length $(\mathrm{cm})$ & $6.88 \pm 0.15$ & $7.06 \pm 0.06$ & $7.00 \pm 0.05$ \\
Whole right epididymal length $(\mathrm{cm})$ & $6.68 \pm 0.15$ & $6.90 \pm 0.08$ & $6.85 \pm 0.04$ \\
Paired epididymal lengths $(\mathrm{cm})$ & $13.54 \pm 0.21$ & $14.01 \pm 0.10$ & $13.85 \pm 0.08$ \\
\hline
\end{tabular}

Means with different superscripts in a column are significantly different $(p<0.05)$. SEM=Standard error of mean

Table-2: Mean ( \pm SEM) epididymal sperm parameters from red Sokoto bucks collected post-mortem, processed without storage, stored at $4^{\circ} \mathrm{C}$ for 24 and $48 \mathrm{~h}$.

\begin{tabular}{lccc}
\hline Parameter & \multicolumn{3}{c}{ Storage hours } \\
\cline { 2 - 4 } & $\mathbf{0}$ & $\mathbf{2 4}$ & $\mathbf{4 8}$ \\
\hline Sperm motility $(\%)$ & $79.93 \pm 0.66^{\mathrm{a}}$ & $69.00 \pm 0.46^{\mathrm{ab}}$ & $50.60 \pm 0.48^{\mathrm{b}}$ \\
Sperm concentration $\left(\times 10^{9} / \mathrm{ml}\right)$ & $2.86 \pm 0.08^{\mathrm{a}}$ & $1.91 \pm 0.03^{\mathrm{ab}}$ & $1.93 \pm 0.03^{\mathrm{b}}$ \\
Sperm viability $(\%)$ & $83.40 \pm 0.58^{\mathrm{a}}$ & $71.27 \pm 0.50^{\mathrm{ab}}$ & $60.47 \pm 0.70^{\mathrm{b}}$ \\
Intact acrosome $(\%)$ & $92.87 \pm 0.39$ & $89.00 \pm 0.29$ & $88.00 \pm 0.39$
\end{tabular}

Means with different superscripts in a row are significantly different $(p<0.05)$. SEM=Standard error of mean 
with the finding of Hoseinzadeh-Sani et al. [37]. The results of this study revealed that viability of epididymal sperm cells declined in a storage time-dependent manner (Table-2). The values of this study were not in agreement with the findings of other researchers who recorded that only sperm motility and not live sperm cells were affected by storage temperature or post-mortem time [4,32]. On the other hand, data in this study are in accordance with the findings in bucks [38] and in red deer [39] that viability of sperm collected from the cauda epididymides post-mortem decreased progressively relative to the time of harvesting spermatozoa.

In this study, the percent intact acrosome decreased significantly $(p<0.05)$ from 0 to $24 \mathrm{~h}$, but not significantly $(\mathrm{p}>0.05)$ from 24 to $48 \mathrm{~h}$ (Table2 ). The results of this study were in agreement with the findings of other scientists [23] who recorded $89.92 \%$ intact acrosome of cauda epididymal spermatozoa collected post-mortem in ram and stored up to $48 \mathrm{~h}$ at $4^{\circ} \mathrm{C}$. These researchers observed that this recorded percent intact acrosome in addition to sperm motility $(44.17 \%)$ and percent livability (78.96\%) of cauda epididymal spermatozoa was of good quality and so indicate their high fertilizing potential. This observation is in agreement with an earlier finding [9].

\section{Conclusion}

Despite the reduction in sperm characteristics during storage, epididymal sperm recovered post-mortem and stored at refrigeration temperature showed good motility, viability, and intact acrosome even after 24-48 $\mathrm{h}$ post-mortem. It is concluded that the testicles of red Sokoto bucks can be held at refrigeration temperature for up to $48 \mathrm{~h}$ until further processing. However, further research is required to determine if there are better methods that can be used to cryopreserve epididymal sperm recovered post-mortem. Furthermore, to increase the value of epididymal sperm retrieved postmortem, research protocols need to be developed that will utilize the harvested sperm cells in reproductive biotechnology.

\section{Authors' Contributions}

AHA planned and conducted the research work; TA helped in laboratory analysis. AIK helped with inputs in planning the research and surgical instruments. AHA, AIK, and TA carried out the statistical analysis and writing of the manuscript; AHA revised the manuscript. All authors read and approved the final manuscript.

\section{Acknowledgments}

The authors thank Professor T. A. Elsa of College of Veterinary Medicine, Federal University of Agriculture, Makurdi, Nigeria for his moral support and Dr. V. Amedu for his technical assistance. This study is a self-sponsored.

\section{Competing Interests} interest.

The authors declare that they have no competing

\section{References}

1. Foote, R.H. (2002) Fertilizing ability of epididymal sperm from dead animals. J. Androl., 23(6): 839-844.

2. Kaabi, M., Paz, P., Alvarez, M., Ariel, E., Boixo, J.C., Rouissi, H., Herraez, P. and Ariel, L. (2003) Effects of epididymis handling conditions on the quality of ram spermatozoa recovered postmortem. Theriogenology, 60(7): 1249-1259.

3. Edeneil, J.P., Valete, E.R.S., Maylem, M.B., Ocampo, E.A. and Lerma, C.O. (2015) Post mortem viability of epididymal sperm from Philippine native water buffalo (Bubalus bubalis). J. Agric. Technol., 11(8): 2283-2294.

4. Martins, C.F., Driessen, K., Costa, P.M., CarvalhoNeto, J.O., De Sousa, R.V., Rumpf, R. and Dodec, M.N. (2009) Recovery, cryopreservation and fertilization potential of bovine spermatozoa obtained from epididymides stored at $5^{\circ} \mathrm{C}$ by different periods of time. Anim. Reprod. Sci., 116(1-2): 50-57.

5. Kikuchi, K., Nagai, J., Kashiwazaki, N., Ikeda, H., Noguchi, J.O. and Shimada, A. (1998) Cryopreservation and ensuing in vitro fertilization ability of boar spermatozoa from epididymides stored at $5^{\circ} \mathrm{C}$. Theriogenology, 50: 615-623.

6. Muradás, P.R., Weiss, R.R., Kozicki, L.E., Granemann, L.C., Santos, I.W. and Pimpão, C.T. (2006) Some viability parameters from equine spermatozoa harvested by artificial vagina and by epididymal tail washing. Arch. Vet. Sci., 11(3): 69-74.

7. Tittarelli, C., Sarignone, C.A., Arnaudin, E., Stornelli, M.C., Stornelli, M.A. and De La Sota, R.L. (2006) Effect of storage media and storage time on survival of spermatozoa recovered from canine and feline epididymides. Theriogenology, 66(6-7): 1637-1340.

8. Toyonaga, M., Kaihara, A. and Tsutsui, T. (2011) The quality of cryopreserved sperm collected from feline caudal epididymides stored at room temperature. J. Vet. Med. Sci., 73(10): 1395-1398.

9. Ringleb, J., Waurich, R., Wibbelt, G., Streich, W.J. and Jowgenow, K. (2011) Prolonged storage of epididymal spermatozoa does not affect their capacity to fertilize in vitro domestic cat oocytes. Reprod. Fertil. Dev., 23(6): 818-825.

10. Lone, F.A., Islam, R., Khan, M.Z. and Soli, K.A. (2011) Effect of transportation temperature on the quality of caudal epididymal spermatozoa of ram. Anim. Reprod. Sci., 123: 54-59.

11. Sankai, T., Tsuchiya, H. and Ogonuki, N. (2001) Shortterm nonfrozen storage of mouse epididymal spermatozoa. Theriogenology, 55: 1759-1768.

12. Chaveiro, A., Cerqueira, C., Silva, J., Franco, J. and Moreira da Silva, F. (2015) Evaluation of frozen thawed cauda epididymal sperms and in vitro fertilizing potential of bovine sperm collected from the cauda epididymal. Iran. J. Vet. Res., 16(2): 188-193.

13. Zemjanis, R. (1970) Diagnostic and Therapeutic Techniques in Animal Reproduction. $2^{\text {nd }}$ ed. Williams \& Wilkins Co., Baltimore.

14. Eljarah, A., Chandler, J., Jenkins, J.A., Chenevert, J. and Alcanal, A. (2013) Usefulness of haemocytometer as a counting chamber in a computer-assisted sperm analyzer (CASA). Anim. Reprod., 10(4): 708-711.

15. Blom, E. (1973) The ultra structure of some characteristic sperm defect and a proposal for a new classification of bull spermiogram. Nord. Vet. Med., 25(7-8): 383-391.

16. Watson, P.E. (1975) Use of a Giemsa stain to detect changes in acrosome of frozen ram spermatozoa. Vet. Rec., 97: $12-15$. 
17. Ogwuegbu, S.O., Oke, B.O. and Akusu, M.O. (1985) Gonadal and extragonadal sperm reserves of Maradi (Red Sokoto) goat. Bull. Anim. Health Prod. Afr., 33: 139-141.

18. Oyeyemi, M.O., Fayomi, A.P., Adeniji, D.A. and Ojo, O.M. (2011) Gonadal and extragonadal spermiogram of Sahel buck in the humid Zone of Nigeria. Curr. Res. J. Biol. Sci., 3(5): 468-471.

19. Ahmad, M., Latif, M., Ahmad, I.H., Khan, N.A. and Anzar, M. (1985) Postmortem studies in infertile buffalo bulls. Anatomical and microbiological findings. Vet. Res., 117: 104-109.

20. Brito, I.F.C., Silva, A.E.D., Unanian, M.M., Dode, M.A.N., Barbos, R.T. and Kastelic, J.P. (2004) Sexual development in early and late maturity Bos indicus and Bos indicus X Bos taurus cross bred bulls in Brazil. Theriogenology, 62(7): 1177-1217.

21. Ugwu, S.O.C. (2009) Relationship between scrotal circumference, in situ testicular measurements and sperm reserve in West African dwarf bucks. Afr. J. Biotechnol., 8: 1354-1357.

22. Keith, L., Okere, C., Solaimam, S. and Tiller, O. (2009) Accuracy of predicting body weights from body conformation and testicular morphometry in pubertal Boer goats. Res. J. Anim. Sci., 3(2): 26-31.

23. Mir, S.S., Lone, F.A., Khan, M.Z., Malik, A.A., Islam, R. and Sofi, K.A. (2012) Effect of cold storage period on the quality of ram cauda epididymal spermatozoa recovered postmortem. Turk. J. Vet. Anim. Sci., 36(6): 683-687.

24. Amann, R.P. and Almquist, J.O. (1962) Reproductive capacity of dairy bulls VIII. Direct and indirect measurement of testicular sperm production. J. Dairy Sci., 45: 774-781.

25. Lima, I.C.S., Andrade, I.R.A., Aguiar, G.V., Silva, M.M., Catunda, A.G.V., Martins, G.A., Gadelha, C.R.F. and Campos, A.C.N. (2013) In vitro evaluation of goat cauda epididymal sperm, cooled in different extenders at $4^{\circ} \mathrm{C}$. Arch. Zootec., 62(239): 429-437.

26. Dong, Q., Rodenburg, S.E., Huang, C. and Vandevoort, C.A. (2008) Cryopreservation of rhesus monkey (Macaca mulatta) epididymal spermatozoa before and after refrigerated storage. J. Androl., 29: 283-292.

27. Kishikawa, H., Kawa, H., Tateno, H. and Yanagimachi, R. (1999) Fertility of mouse spermatozoa retrieved from cadavers and maintained at $4^{\circ}$ C. J. Reprod. Fertil., 116: 217-222.

28. Karja, N.W.K., Respaty, E.M.A., Nuraini, I., Prihatno, S.A. and Gustari, S. (2010) Characteristic of frozen-thawed epididymal spermatozoa and refrigerated storage of ram spermatozoa. J. Indonesian Trop. Anim. Agric., 35: 63-67.

29. Weiss, R.R., Muradás, P.R., Graneman, L.C. and Meira, C. (2008) Freezing sperm from cauda epididymis of castrated stallions. Anim. Reprod. Sci., 107(3-4): 302-360.

30. Tajik, P. and Hassan-Nejad Lamsoo, M.R. (2008) Assessment of epididymal sperm obtained from dromedary camel. Iran. J. Vet. Res., 9: 46-50.

31. Lubbe, K., Bartels, P., Kilian, I., Friedmann, Y. and Godke, R.A. (2000) Comparing motility and morphology of horse, zebra and rhinoceros epididymal spermatozoa when cryopreserved with two different cryodiluents or stored at $4^{\circ} \mathrm{C}$. Theriogenology, 53: 338 .

32. Bertol, M.A.F., Weiss, R.R., Thomaz-Soccol, V., Kozicki, L.E., Fujita, A.S., Azevedo de Abreu, R. and Green, K.T. (2013) Viability of bull spermatozoa collected from the epididymis stored at $18-20^{\circ} \mathrm{C}$. Braz. Arch. Biol. Technol., 56(5): 777-783.

33. Martinez-Pastor, F., Diaz-Corujo, AR., Anel, E., Herraez, P., Anel, L. and de Paz, P. (2005) Post mortem time and season alter subpopulation characteristics of Iberian red deer epididymal sperm. Theriogenology, 64: 958-974.

34. Bergeron, A. and Manjunath, P. (2006) New insight towards understanding the mechanism of sperm protection by egg yolk and milk. J. Mol. Reprod. Dev., 73: 1338-1344.

35. Daudu, C. (1984) Spermatozoa output, testicular sperm reserve and epididymal storage capacity of the red Sokoto goats indigenous to Northern Nigeria. Theriogenology, 21: 317-324.

36. Abba, Y. and Igbokwe, I.O. (2015) Testicular and related size evaluations in Nigerian Sahel goats with optimal cauda epididymal sperm reserve. Vet. Med. Intern., 2015: Article ID: 35751. Available from: http://www.dx.doi. org/10.1155/2015/357519.

37. Hoseinzadeh-Sani, S.K.A., Barati,F. and Mahabady, M.K.M. (2013) The effects of ex vivo cold-storage on cryopreservation of the goat (Caprus hircus) epididymal sperm. Iran. J. Reprod. Med., 11(9): 747-752.

38. Nasir, M., Njidda, A.A. and Hassan, A.M. (2014) Testicular histometry, gonadal and extra gonadal sperm reserve of red Sokoto bucks fed cotton seed cake. J. Sci., 4(4): 227-232.

39. Garde, J., Ortiz, N., Garcia, A., Gallego, L., Landete, C.T. and Lopez, A. (1998) Post-mortem assessment of sperm characteristics of the red deer during the breeding season. Arch. Androl., 41(3): 195-202. 